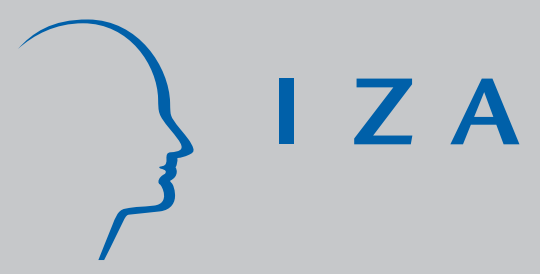

IZADP No. 1806

Demographic and Education Effects on Unemployment in Europe:

Economic Factors and Labour Market Institutions

Federico Biagi

Claudio Lucifora

October 2005 


\title{
Demographic and Education Effects on Unemployment in Europe: Economic Factors and Labour Market Institutions
}

\author{
Federico Biagi \\ Università di Padova and SDA Bocconi \\ Claudio Lucifora \\ Università Cattolica, FEEM, CEPR \\ and IZA Bonn
}

Discussion Paper No. 1806

October 2005

\author{
IZA \\ P.O. Box 7240 \\ 53072 Bonn \\ Germany \\ Phone: +49-228-3894-0 \\ Fax: +49-228-3894-180 \\ Email: iza@iza.org
}

\begin{abstract}
Any opinions expressed here are those of the author(s) and not those of the institute. Research disseminated by IZA may include views on policy, but the institute itself takes no institutional policy positions.

The Institute for the Study of Labor (IZA) in Bonn is a local and virtual international research center and a place of communication between science, politics and business. IZA is an independent nonprofit company supported by Deutsche Post World Net. The center is associated with the University of Bonn and offers a stimulating research environment through its research networks, research support, and visitors and doctoral programs. IZA engages in (i) original and internationally competitive research in all fields of labor economics, (ii) development of policy concepts, and (iii) dissemination of research results and concepts to the interested public.
\end{abstract}

IZA Discussion Papers often represent preliminary work and are circulated to encourage discussion. Citation of such a paper should account for its provisional character. A revised version may be available directly from the author. 


\section{ABSTRACT \\ Demographic and Education Effects on Unemployment in Europe: Economic Factors and Labour Market Institutions ${ }^{*}$}

We analyse the effects of demographic and education changes on unemployment rates in Europe. Using a panel of European countries for the 1980-2000 period - disaggregated by cohort, gender and education -, we empirically test the economic effects of two stylised facts that have occurred in recent decades: the "baby bust" and the "education boom". We find that structural shifts in the population age structure play an important role and that a lot of variation is also attributable to educational changes, the latter usually neglected in aggregate studies. Results show that demographic and education shocks are qualitatively different for young (adult) workers as well as for more (less) educated people. While adult workers and more educated individuals, in general, experience lower unemployment rates, changes in the population age structure appear to be positively related to young workers' unemployment rates while they have no effect on adults. Conversely changes in the skill structure ("education boom"), even when controlling for skill-biased technological change, reduce the unemployment of the more educated. Labour market institutions also influence unemployment rates in different ways. Unemployment benefits are found to have a positive impact on unemployment, while bargaining coordination and employment protection reduce it.

JEL Classification: $\quad$ E24, J31, J51, J65

Keywords: unemployment, demographic, education, labour market institutions

Corresponding author:

Claudio Lucifora

Università Cattolica

Largo Gemelli 1

20123 Milano

Italy

E-mail: claudio.lucifora@unicatt.it

\footnotetext{
* We are grateful to Andrea Bassanini, Giorgio Brunello, Charlotte Lauer, Juan Jimeno, Luca Nunziata and project partners for helpful comments. This paper is part of the project "Education and Wage Inequality in Europe" [EDWIN]. Financial support from the European Commission under the $V$ framework research project [contract number: HPSE-CT-2002-00108] is gratefully acknowledged. Data on labour force and wages have been kindly provided by project partners, Juan Jimeno (for Spain), the Bank of Italy (for Italy) and the Oecd. We are also grateful to Steve Nickell and Luca Nunziata who have kindly supplied data on labour market institutions. Usual disclaimers apply.
} 


\section{Introduction}

In recent decades most European economies have experienced a number of demographic shifts which have significantly altered the population age structure and changed the relative position of young versus prime-age workers in the labour market. Over the period 1970-2000 the ratio of the youth population to the adult population increased in most countries during the 1970s and 1980s and then fell in the following decades. Average unemployment rates for young people increased significantly, up to the late 1980s, then slightly decreased in the following decades, while adults' unemployment varied only marginally. Also unemployment rates by educational levels show significant variation: more educated workers are two to three times less likely to be unemployed as compared to their low education counterparts and over the business cycle their relative rates tend to diverge.

Almost all European countries experimented also an increase in the educational levels over the past decades: in this scenario the countries with traditionally low levels of education (at the start of the period) are catching up and the number of high-skilled people is growing in absolute and relative terms.

These patterns are highly policy-relevant and have attracted the interests of both economists and policymakers stimulating extensive research and a fierce debate on the economic effects of the increase in the youth share of population, and the relationship with the rise and the persistence of (youth) unemployment. The terms "baby boom" (and "baby bust") have been used in the literature to indicate the substantial increase (decrease) in the size of younger cohorts and other similar changes in the population age structure; while "generational crowding" has been often used to define the worsened economic conditions for the younger cohorts (OECD, 1986, Korenman and Newmark, 2000). Similarly another strand of literature has tried to investigate the effects of supply (the "education boom") and demand shocks (skill biased technological progress) on both unemployment and earnings (EU-Irs, 2000; Bertola et al, 2002a; Brunello et al., 2000; Flinn, 1993). Although these patterns have some common grounds in most European countries, yet it should be stressed that the aggregate evidence conceals a lot of heterogeneity - both across countries as well as between different groups of individuals within each country - and limits significantly our ability to understand which factors are at work in the above scenario.

Along with demographic shifts and changes in the (relative) demand for education, other relevant factors - both of cyclical and structural nature - have also contributed to the fortunes of youths in the labour market, for example to name a few: business cycle fluctuations, changes in 
participation rates by gender and age, changes in schooling patterns and school-to-work transitions, technological change and the role of labour market institutions.

While, on the basis of standard textbook's 'supply-demand' analysis, there seems to be consensus that an increase (decrease) in the youth share of population - ceteris paribus - will eventually have a depressing (improving) effect on the economic opportunities of those participating to the labour market, yet consensus among economists on the empirical relevance of the above phenomena is still lacking. The large number of empirical studies that have investigated the economic effects of cohort size, on youth earnings and unemployment, are often difficult to compare due to data and methodological differences, and even when a comprehensive review of the studies is considered and the issue of comparability is carefully addressed, still a great deal of heterogeneity by country and time seem to characterise the experience of European countries (Zimmerman, 1991; Korenman and Newmark, 2000; Jimeno and Rodriguez-Palenzuela, 2002).

Finally, on some of the relevant issues research is still very scarce. For example, while there is some evidence that the effects of changing population age structure on unemployment are not necessarily symmetric, most studies have analysed the economic outcomes under the "baby boom" scenario, and little is still known as to the outcomes under the more recent "baby bust" scenario. Also, while we have significant evidence on the economic effects of demographic shocks on the (un)employment and earnings of youths, we know very little of the likely interactions by educational achievement and skill levels within and across cohorts and by gender.

Hence a number of questions are in order. What is the recent evidence about the (un)employment conditions of different cohorts in Europe and how the picture varies according to educational levels? Which are the countries, in Europe, that have been more (less) severely affected by both demographic shocks and changes in the skill structure, and what are the various trade-offs? What is the evidence on the changing fortunes of European young (adult) workers, in terms of employment opportunities, following demographic and (skill-biased) technological shocks? Which other economic factors, besides population changes by age and skills, have played an important role in the labour market fortunes of European workers? To what extent labour market institutions have contributed to the worsening of the economic opportunities of the least protected workers, or have slowed down the process of adjustment putting all the burden on some group of workers?

This paper intends to address some of the above questions and contribute to the literature extending previous findings in a number of ways. First it uses a unique data set that combines data from different sources and for a relevant time period - for various European countries and provides a disaggregation by educational levels which has not been used before. Second, it provides an analysis of the European "baby-bust" phenomenon accounting for both the effects of demographic 
and educational shifts. Third, it extends the early findings to more recent data, thus providing new evidence on the recent evolution of European labour market and discusses policy options in the light of the European Employment Strategy (EES). Finally, in contrast with the previous literature, it argues that an important part of the effects of demographic changes on unemployment rates can be explained by shifts in the supply and demand of more (less) educated workers. The paper is organised in the following way. In section 2 the relationship between demographics and unemployment, and the relevant literature is reviewed. Section 3 presents the data and some descriptive evidence. In section 4 and 5 we discuss the main results, also with reference to the role of labour market institutions. Section 6 summarises the main findings and concludes.

\section{The Economic Implications of Demographic and Education Composition on Unemployment: a Review of the Literature}

Empirical evidence on the economic effects of cohort size on unemployment rates is extensive and covers a large number of countries and time periods. While most of the studies concern the US experience, empirical evidence has also become increasingly available for Europe and a number of OECD countries. Results from the empirical literature are somewhat controversial. Most available evidence suggests that a large cohort size will (negatively) affect the earnings levels of the individuals (mainly of that cohort), as well as their (un)employment status (or labour force participation). The relevance of the two effects are likely to depend on a number of factors such as the functioning of the labour market, the state of the business cycle, public policies and, not least, the relevance of labour market institutions ${ }^{1}$. Typically, studies for the US have found that relative wage effects are more important in the adjustment process following a demographic shock, although in some cases the effects on wages can persist over time (Flaim, 1979; Welch,1979; Berger, 1985). Differences in the effects on earnings have also been shown to depend on substitutability between young and adult workers and skill levels (i.e. more educated tend to be more severely affected) as well as to the mobility decisions of individuals (Stapleton and Young, 1988; Bloom, et al. 1987; Wright,1991; Nickell,1993) ${ }^{2}$. Conversely, empirical evidence for European countries has shown that unemployment and out-of-labour force are the most likely effects of a demographic shock (Korenman and Newmark, 2000). Other studies have found instead

\footnotetext{
${ }^{1}$ For example, depending on the elasticity of the labour demand the effect on wages will be more or less pronounced, wage rigidity or a statutory minimum wage may produce significant spillover to (un)employment. Macroeconomic conditions too may have an impact in the adjustment process by absorbing more or less easily the supply shock. Finally, also direct employment creation, collective bargaining and employment protection legislation may have an impact.
} 
that a larger share of the youth population may reduce unemployment if labour markets are imperfect and there are trading externalities in firms' job posting and workers' search behaviour (Shimer, 2001; Nordstrom Skans, 2002).

While an extensive review of the empirical evidence is beyond the scopes of the present paper, excellent reviews - with a wide coverage of the literature - are available, see for example among others: Bloom, et al. (1987), Korenman and Newmark (2000), and Johnson and Zimmerman (1993). Here we focus only on few papers that have specifically addressed the relationship between the population age structure and (un)employment rates in a cross-country (state) perspective thus providing a good starting point for a discussion on data, methodology and results. Also, in the literature examined, we found relatively little empirical evidence on the relevance of population age structure by educational achievements and, in most of the cases, this evidence dealt almost exclusively with earnings. The latter is somewhat surprising given the importance that skill (biased) technological changes have in the explanation of several labour market phenomena (Katz and Autor, 1999). For this reason, even if the main focus in this paper is on the relationship between the population age structure and (un)employment rates, among the studies reviewed below we also include those focused on earnings.

The labour market consequences of generational crowding for selected industrialised countries (Australia, Canada, France, Japan, Sweden, UK and US) are analysed in Bloom et al. (1987) who try to discriminate between two alternative views: first, that low earnings and high unemployment for the young are in general age-related, and hence temporary; or second, that they emerge when a large cohort enters the labour market, and hence, being cohort specific, tend to be permanent. They survey several empirical studies which have investigated the effects of cohort size on earnings and unemployment in a number of countries and report that the evidence suggest a negative impact of large cohort size on (expected) earnings and a marked trade-off between the relative earnings effect and the relative employment effect. Their results confirm the evidence from previous literature and show that the effect of cohort size is stronger on relative earnings in some countries (US and Australia), on relative (un)employment in others (Canada, France and UK) while little or no effects is detected in some others (Sweden and Japan); the latter is interpreted in terms of influence of institutionally-determined factors. Also, cohorts that have been hit more severely by the change in the population age structure are found to converge to the patterns that would have resulted otherwise, but their lifetime (expected) earnings appear to be permanently reduced.

\footnotetext{
${ }^{2}$ It has been argued that individuals hit by an adverse shock tend to move to states or regions where unemployment is lower and the re-employment probability higher.
} 
In a more recent study, Korenman and Newmark (2000) investigate the effects of changes in the population age structure on the economic conditions of young people in labour markets in a number of advanced economies (US, Canada, Australia, Japan and other European countries) over the 1970s, 1980s and early 1990s. They provide an extensive survey of more recent empirical studies which show a rather more mixed evidence: on the one hand main results seem to support the economic effect of cohort size on relative earnings and (un)employment as found in the previous literature; on the other hand, they highlight a number of data and methodological problems that concerns empirical findings. For example, it is stressed the importance of using cross-section timeseries data, for the lack of cross-national (or state) variation in the data relating to the size or timing of the demographic shocks may confound cohort and time effects (i.e. such as business cycle) making results difficult to interpret (Flaim, 1979, 1990; Nardone, 1987) ${ }^{3}$. Furthermore, the potential endogeneity of relative cohort size is discussed since migration decisions of workers or schooling decisions may be related to economic conditions and, finally, particular care is paid to the role of labour market institutions in influencing the sensitivity of the relationship between cohort size and (un)employment. Their main conclusions lead to the finding that large youth cohorts significantly affect the relative unemployment rate of younger workers relative to adults - i.e. with an elasticity close to 0.5 - and that institutional settings that decrease flexibility may lead to greater fluctuation in the (un)employment rates of youths.

These findings are challenged by Shimer (2001), who, using data for US states from the late 1970s to the late 1990s, finds that an increase in the youth share of the working age population reduces significantly both the youth and the adult unemployment rates (i.e. the former with an elasticity close to -1.5 , while close to -3.0 for the latter). When focusing on relative young/adult unemployment rates, the previous finding implies that an increase in the youth share of the working age population can cause a sharp reduction in the relative young/adult unemployment rate. This result is contrary to what standard economic theory would predict and it is actually consistent with models in which workers of different ages are not perfect substitutes and labour market frictions are present.

A number of more recent studies have concentrated attention, in particular, on the role of the institutional settings and the effects on relative unemployment rates. Jimeno and RodriguezPalenzuela (2002), for example, extend and update some of the previous studies using a panel of 19 OECD countries over the period 1968-1996, putting particular emphasis on the role of the institutional setting to explain the differences in (un)employment rates, by gender and cohort,

\footnotetext{
${ }^{3}$ The problem can be illustrated as follows, when a large cohort size enters the labour market and the economy is in a slack, it might be difficult to determine the relative importance of the two effects. However, if there is enough variation
} 
between the US and European countries. Their empirical findings suggest that some labour market institutions have contributed to increase youth unemployment and that the burden of adjustment to demographic and macroeconomic shocks has been borne mainly by young workers, as compared to adult workers. In a similar way, Bertola et al. (2002b) find that the interaction between economic (and demographic) shocks and labour market institutions are more relevant for the composition of employment and the incidence of unemployment (for example, by age and skill) in the working-age population, rather than on the overall level. They also show that demographic shocks interacted with some labour market institutions can explain much of the differences in unemployment rates of young and female workers between the US and EU countries. As previously mentioned, some of the above results are difficult to reconcile mostly due to difference in the data and the level of aggregation, and with respect to the estimation strategy. Korenman and Neumark (2000), for example, only consider two cohorts, making no distinction by gender or education, while Jimeno et. al (2002) and Shimer (2001) maintain the hypothesis of a common aggregate demographic shock (measured by the relative share of the young and adult cohort) but allow its effect to differ across gender or age groups ${ }^{4}$. As for the estimation strategy, Korenman and Neumark (2000) and Jimeno et. al (2002) regress relative unemployment rates on relative population shares (i.e. young versus adult) finding a positive relationship between the two and interpret it as being consistent with the cohort crowding hypothesis. This approach, as already mentioned, is challenged by Shimer on the ground that it hides the "true" relationship between the demographic shocks and the levels of the unemployment rate for the various groups and can lead to spurious relations. Regressing the log of state, age and gender specific unemployment rates on the share of the youth population over the total population in each state, he finds a negative coefficient thus suggesting that an increase in the share of the young cohorts in the population, contrary to the crowding out hypothesis, reduces the unemployment rate. However, since the effect is higher (in absolute value) for the adult cohort, it shows as an increase in the relative unemployment rate of the young cohorts.

Although many of the studies reviewed above note the relevance of educational choices, enrolment rates and returns to education in assessing the effects of demographic shocks on earnings and (un)employment, there is still relatively little empirical evidence looking at the implications of the population age structure by schooling achievements in a cross-country perspective. Stapelton and Young (1988) investigate the effect of cohort size on returns to education and on schooling attainment for the US. They argue that if substitutability between young and adult workers is inversely related to education (i.e. it declines as education increases), highly educated workers 
belonging to large cohorts are likely to be worse off, in terms of present value of lifetime earnings, as compared to less educated workers and will, ceteris paribus, invest less in human capital. Their findings confirm a decline in college completion rates of baby-boomers, between the 1970s and 1980s, and an increase for those (baby-bust) cohorts that came after the demographic shock ${ }^{5}$. Card and Lemieux (2001), Brunello et al. (2000), and Brunello and Lauer (2004) analyse the effect of the relative supply of highly-educated workers across cohorts on the college-high school wage gap. In the first study Card and Lemieux (2001), using cross-country evidence for the US, UK and Canada, show that the elasticity of substitution between different age groups is finite and larger than that between different education groups. Also, the age distribution of educational attainment is found to be very important in explaining the change in the distribution of wages and the increase in the college wage premium occurred in the countries considered over recent decades. In the second study Brunello et al. (2000), using data for 10 European countries and two cohorts, show that there is significant heterogeneity across European countries in terms of college-high school wage gap for different age groups. In particular, the main findings suggest that institutions play a relevant part in shaping the evolution of educational wage differentials face to economic and demographic shocks. In the latter study Brunello and Lauer (2004) document a (small) negative and statistically significant effect of cohort size on earnings, that varies by education and age, while the impact of demographic changes is found to be stronger than the impact of educational changes. Moreover they find that the effects of changes in the demographic and education composition of the workforce are stronger in southern European countries and for older individuals, even after controlling for institutional variables that characterize the labor market. This evidence is interpreted as reflecting a two-tier system, particularly evident in the Southern European countries, by which high employment protection tends to generate a relatively protected sector, where wages are relatively inflexible and a non protected sector, in which wages adjust to supply and demand shifts. The findings of this study are particularly relevant for our purposes since they document that the wage elasticities to shifts in the composition of the work force are quite low. This clearly call for an analysis of the potential effect of demographic changes on unemployment.

The main findings from the literature reviewed - even if some care should be used when comparing studies which are different in terms of data, methodology and coverage - draw attention

\footnotetext{
${ }^{4}$ The relevant aggregate demographic variable can be defined at the State level, as in Shimer (2001), in which case it is a State-specific aggregate demographic shock.

${ }^{5}$ Note that in this case, the cohorts that follows the baby-boomers will have both lower opportunity cost of investment in human capital with no decrease in returns, so the effects will be particularly significant. Flinn (1993) also reaches similar results analysing on-the-job training patterns for the US. Wright (1991) analysing cohort crowding effects for Great Britain finds a greater impact on earnings for more highly-educated workers. Conversely an opposite conclusion is reached by Hartog et al. (1993), who find a lower impact on earnings levels of large size cohorts of high-educated workers with respect to less-educated ones.
} 
to a number of open questions. First, there is contrasting evidence on the sign of cohort size effects on unemployment. Second, there is evidence that results depend on the chosen definition of (relative) cohort and unemployment, and on the specification used - i.e. controlling for the business cycle, cohort's position in the demographic cycle, country and time fixed effects, and other features. Third, studies based on very aggregate data, by assuming perfect substitution across age groups, gender and skills, can distort the overall picture. Fourth, there is indirect evidence that cohort size effects are stronger for some group of workers (i.e. more educated), although this issue has not been adequately addressed. Fifth, while labour market institutions and policy measures seem to matter a lot for (un)employment rates the evidence, particularly in European countries, is still scarce.

\section{Data and Descriptive Evidence}

The data we use contain information on population, employment and labour force for ten European countries from 1975 to 2002 (depending on the country). The dataset is structured as a panel further disaggregated by gender, cohort (age groups, 15-24, 25-54 and 55-64) and educational levels (primary, upper secondary and tertiary according to the ISCED definition) ${ }^{6}$. Table 1 below reports, for each country covered, the source of the data and the period available ${ }^{7}$.

[Tab.1]

The empirical analysis restricts the focus to two cohorts: "young" (Y; age 15-24) and "adults" (A; age 25-54), since the inclusion of the "old" cohort (age 55-64) would have implied a significant number of missing observations. Additional information on business cycle indicators and labour market institutions has been collected and matched to the above data set ${ }^{8}$.

To get a rough idea of the overall demographic and education patterns, over the period considered, in Figure 1 we report the aggregate demographic trends (i.e. Yshare - the share of the young cohort over the 15-54 population) and the aggregate changes in the education composition (i.e. Eshare the share of those who have achieved upper secondary education or more over the 15-54 population) for each of the countries considered. ${ }^{9}$

[Fig.1]

\footnotetext{
${ }^{6}$ In practice, primary corresponds to ISCED levels 0 to 2, secondary to ISCED 3 and tertiary to ISCED 5 and 6.

${ }^{7}$ In a Statistical Annex (available upon request), we aggregate up our data to compare it with OECD data used in most of the previous studies.

${ }^{8}$ As a business cycle indicator we have computed GDP deviations from a linear trend (source: ENERDATA). Some unpublished data have been provided by OECD, while data for Spain have been kindly made available by Juan Jimeno. Labour market institutions data have also been kindly provided by Steve Nickell and Luca Nunziata. The following variables are available for the 1970-1998 period: net union density, bargaining coordination, tax wedge, employment protection, unemployment benefit duration and benefit replacement rate.

${ }^{9}$ Notice that the variable Yshare captures only the effects of demographic changes, regardless of educational changes.
} 
Figure 1 shows that all countries (with perhaps the exception of post-reunification Germany) have experienced a decline in the youth population share (the "baby bust"): up to 1995, this decline is particularly evident for the UK, Sweden and Norway, while after 1995 the decline is stronger for the Southern countries (Spain, Italy, Portugal and Greece), reflecting difference in the timing of the changes in the demographic composition for European countries. At the same time, a significant rise of the share of educated took place for most countries (the "education boom"). A substantial difference between Northern and Southern European countries is apparent: in the former group of countries the process of educational upgrading originated much earlier, so that in 1980 the proportion of the population with secondary education or more was well above 20 percent (see Norway, Sweden, the UK, France and Germany); in the latter, the share of the more educated, at the beginning of the 1980s, was still close to 15 percent (Italy, Portugal, Greece and Spain). A significant rise in Spain and Greece occurred in later years, while Italy and Portugal seem to be lagging behind. One important aspect has to do with the interpretation of the trend reported in Figure 1, since it can be due to both changes in school-leaving-age legislation as well as to individual choices. Concerning the first aspect, a reform of the educational system increasing compulsory education (for a given demographic composition) would have a temporary effect on the ratio: an increase in the number of those registered as having primary education or less and a decrease in the number of those registered as having secondary education or more. This would be a pure cohort effect and would disappear with time. As to the educational choices of the different cohorts, several factors affecting both the costs as well as the expected returns of education (which besides institutional factors also depend upon employability and wages) may have played a role ${ }^{10}$.

[Tab.2]

Looking at the patterns of youth unemployment for the last decade (since 1991) we notice a group of countries (Germany, Norway, Portugal, Sweden and the UK) which are characterised by low unemployment rates - on average less than 16 percent - while the remaining countries (Finland, France, Greece, Italy and Spain) show rates ranging between 22 and 38 percent (France and Italy respectively). Over the same period the mean of the adult unemployment in the first group of countries is between 4 and 8 percent and 9 to 16 percent in the second group. The same grouping of countries can be recognised when we analyse the average unemployment rates by educational levels. Relative unemployment rates by age groups show that youth unemployment is, in general two to three times higher than adult unemployment (with the only exception of Germany where is

\footnotetext{
${ }^{10}$ This of course implies that educational choices might be endogenous. This point is addressed in a later section when discussing the estimation strategy.
} 
almost the same). Conversely, when we compute relative unemployment rates by skill (last column of Table 2), we find that the ratio is, for most countries, slightly above 1 (with the exception of the UK where is higher), while in some countries (Italy, Greece, Portugal and France) the average unemployment rate of the more educated is higher compared to the one of those with only primary education. Hence, there seems to be substantial variation across countries in the relative unemployment rates by age and educational groups that needs to be explained.

\subsection{Demographic and Education Changes}

Most of the existing research on the effects of demographic shocks on unemployment has mainly focused on aggregate or cohort specific factors (Shimer, 2001; Jimeno et al., 2002). In the former case, the implicit assumption is that individuals belonging to different cohorts (young or adult) are perfect substitutes in production, that is the only thing that matters is the overall supply of workers and the effect produced on the aggregate unemployment rate. Alternatively, in the latter case, when the focus is on relative cohort effects and relative unemployment rates (i.e. young-adults) some allowance is made for the fact that workers of different ages might be imperfect substitutes in production and that the relative (un)employment rates will be somehow proportional to the (relative) demographic shock and to the (in)ability of (relative) wages to adjust. One problem with the above approach is that it completely neglects the role that skills and education have in production or, that is the same, it assumes that workers with different skills and education are perfect substitutes in production. This, as already noted, is quite surprising given the emphasis that explanations based on skill-biased technological changes have received in accounting for a wide range of economic facts occurred to developed countries in recent decades, such as increasing inequality to the evolution of skilled-unskilled relative unemployment rates (Nickell and Bell, 1996; Acemoglu et al., 2001; Acemoglu, 2003).

In other studies, cohort size has been defined as the proportion of an age group in the total population with the same educational attainment; in this case, however, the implicit assumption is that the labour market is segmented by education and that substitution across educational groups is very difficult (Welch, 1979). In other words, under this definition of cohort size, changes in the number of young individuals with a given education level should have no effect on the employment opportunities of young and old individuals possessing a different educational level. This makes difficult to disentangle the effects of demographic and the educational shocks on the unemployment rate. In the light of the above, the choice of the appropriate level of aggregation is crucial. We specify the unemployment rate by gender, cohort and education groups for each country and year; while the demographic and the education composition of the population will be specified at 
different levels of aggregation depending upon the unemployment-generating mechanism and the (shape of) production function ${ }^{11}$.

A second issue is concerned to wage formation. Some studies assume from the start that wages are fully flexible thus ruling out unemployment (Card and Lemieux; 2001); conversely, among those studies focussing on unemployment, most have assumed wage rigidity or some form of wage bargaining which, together with the characteristics of the production function, generates equilibrium wages and unemployment (Jimeno and Rodriguez-Palenzuela; 2002).

In this paper, to estimate the relationship between group specific unemployment rates, aggregate demographic changes and aggregate changes in the education composition, we use a reduced-form approach which is consistent with a nested CES approach and with frictions in wage adjustments arising from wage bargaining and other labour market institutions. Also, we retain Shimer's intuition suggesting that what is of interest here is the relationship between the levels of the unemployment rate - by age, education and gender groups - and demographic (and education) shifts. Hence the aggregate shifts we use, as previously defined, are: Yshare, for the demographic changes and Eshare, as a proxy for the share of skilled human capital. We also experimented a different definition for education changes, EshareY, as the share of those with upper secondary education or more within the young cohort (i.e. the 15-24 age interval), thus proxying for the distribution of skills and human capital within the youngest cohort. The main difference between the two definitions above is that, according to Eshare what matters is the overall share of those more educated, while according to EshareY individuals compete mainly with those entering the labour market roughly at the same time (captures the effects of changes in the share of those getting more education within the youngest cohort) ${ }^{12}$. Notice also that while Eshare mixes the effects coming from the demographics with those coming from shifts in the education composition, EshareY captures exactly the education composition of the young cohort conditional on the demographics.

Our data document a significant across-country heterogeneity in the evolution of unemployment by age and educational achievements and highlight the complex dynamics which underlies demographic and skill changes. Moreover, across-country variation in the patterns of unemployment might be related to frictions (institutions or other features) preventing labour market clearing. Henceforth, while some common demographic trend can account for unemployment patterns over time, the heterogeneity of individual country experience both in the levels and in the age-education structure of unemployment calls for an explanation. The studies reviewed above

\footnotetext{
${ }^{11}$ Card and Lemieux (2001) and Jimeno and Rodriguez-Palenzuela (2002) used a CES specification.

12 The impact of this variable on unemployment captures, conditional on the aggregate demographic shock, whether being better educated affects the (un)employment rate. In other words, being high skilled within an age group in which
} 
suggest that along with demographic, also educational shocks and other factors may account for some of the observed evidence.

As a first step, we explore the patterns in terms of gender-cohort-education specific effects controlling for country-time specific effects in unemployment. As shown in [1] below, to do this we simply regress the group specific unemployment rates, on country, time and other group dummies ${ }^{13}$,

$$
u n_{s j i c t}=s_{s}+c_{j}+e_{i}+C_{c}+T_{t}+\varepsilon_{\text {sjict }}
$$

where $u n_{\text {sjict }}$ stands for unemployment for the $(s)$ gender, $(j)$ cohort $(i)$ education, $(c)$ country and (t) time breakdown, $\boldsymbol{s}, \boldsymbol{c}$ and $\boldsymbol{e}$ are set of dummies for gender, cohort and education, $\boldsymbol{C}$ is a country fixed effect, $\boldsymbol{T}$ is a common time effect, and $\varepsilon_{\text {sjict }}$ is the residual term. This decomposition allows us to get a general idea of the patterns of unemployment in Europe - i.e. given time invariant country effects and common time effects. For example, estimating equation [1] over the 1990-2002 period considered, we find that youth unemployment was on average 13 percent higher than adult unemployment while unemployment among college educated youths was only 4 percent (1.8 percent) lower than the unemployment rate among those with primary (upper secondary or more) education. Considering gender differences, we notice that unemployment is $3 \%$ higher for women. Alternatively, if we take two countries, say Italy and Germany, the estimated country effect are, respectively, 0.18 and 0.001 percent suggesting strong country specific differences in unemployment rates.

Finally, when we compare the predicted with the actual rates we find that, relative to any other dimension, our model performs poorly in terms of the age structure of unemployment: in particular, youth unemployment is overestimated, while adult unemployment is underestimated with respect to what a "common" behaviour in Europe would have implied. How can we explain this patterns in the residual? Clearly, there are lot of important factors missing in equation [1], and the age structure of the population and the educational composition are good candidates to reconcile the evidence.

\subsection{Discussion}

Given our definition of the relevant variables and the chosen framework of analysis, in which wages are (at least partially) inflexible, a simple demand-supply model would predict that, everything else constant, a (negative) demographic shock (the "baby bust") should tend to favour young cohorts within every skill group, while an increase in the relative size of the population with higher education should worsen the relative position of skilled workers. In this purely supply-side

many people are also high skilled may, in the presence of wage rigidity, increase competition for available jobs and reduce employment opportunities. 
framework (which would have a hard time explaining why we observe such a huge change in the education composition in the first place) the presence of both a "baby bust" and an increase in the educational attainment of the population (conditional on the demographics), suggest that young cohorts of unskilled workers should be relatively better off, while adult cohorts of skilled workers should be relatively worse off (within this context, "better/worse off" means lower/higher unemployment $)^{14}$. As for the other groups, the relative effects would depend upon the relative importance of the demographic versus the education compositional change. One complication with respect to the above supply-side framework is that relative demand for skills might also change ${ }^{15}$. For example, an increase in the relative demand for skilled labour would easily accommodate the higher share of skilled workers with ambiguous effects on the relative unemployment rate. In other words, given the demographics and the shifts in education composition just described, even the effects for the two groups previously mentioned may become ambiguous: young cohorts of unskilled workers are now affected by a demand shift that makes them worse off and adult cohorts of skilled workers are now affected by a demand shift that makes them better off.

[Fig. 2]

If we focus only on the young cohort and use a simple two sectors demand-supply framework for the analysis (as in Figure 2), a picture that can prove consistent with the empirical evidence previously described would imply an inner shift of the supply schedule (i.e. the baby bust) in both sectors; an increase in the share of more educated people (i.e. the education boom) in the more educated labour market, while leaving largely unaffected the market for low educated individuals. On the demand side, technological change (skilled-biased) would shift the demand for more educated labour outward while an opposite shift would be observed in the low education market. Depending on the relative shifts and the extent of wage rigidity caused by institutions and other frictions, an excess demand (ED in Figure 2b) may be observed in the market for more educated labour, while unemployment (UNE in Figure 2a) may emerge in the market for low education labour. Therefore, even in a simple world such as the one described above, the overall effect is mainly an empirical question. Before turning to the estimates, we need to discuss the issue of endogeneity. First, if young workers move across countries according to the available employment opportunities, then the share of young workers in the population and their unemployment rate are likely to be co-determined (i.e. due to a "job search" migration effect). Second, when considering

\footnotetext{
${ }^{13}$ The unemployment rates are defined for time, country, gender, cohort and education specific cells.

${ }^{14}$ In relative terms here means: when compared to both young cohorts of skilled workers and old cohorts of unskilled workers, in the first case, and when compared to both old cohorts of unskilled workers and young cohorts of skilled workers, in the second case.

${ }^{15}$ As shown by the large literature on the skill-biased technological change.
} 
educational choices it cannot be excluded that they are potentially affected by the same variables determining labour market outcomes (i.e. unemployment). While we can reasonably exclude that migration of young individuals across European countries is sizeable and thus consider that the demographic composition is exogenous, the same might not be true for education choices. Hence at the estimation stage we need take into account the issue of potential endogeneity for the variable capturing the educational composition.

\section{The empirical model}

The effect of demographic and educational changes on unemployment is first captured by aggregate terms ${ }^{16}$. Our basic specification is, ${ }^{17}$

$\ln u n_{s j i c t}=\alpha \ln$ Yshare $_{c t}+\beta \ln$ Eshare $_{c t}+\gamma$ Dem $_{c t}+s_{s}+c_{j}+e_{i}+C_{c}+T_{t}+\varepsilon_{\text {sjict }}$

where $\ln u n$, is the log of unemployment, as previously defined, $\ln$ Yshare $_{c t}$ and $\ln$ Eshare $_{c t}$ are the $\log$ of the demographic and education terms in country $c$ and year $t, \operatorname{Dem}_{c t}$ is a demand shifter (which is also country and time specific), the other terms are control dummies, the parameters to be estimated and an error term ${ }^{18}$. Since we are interested in the differential effects of the aggregate shocks across different group, we have also interacted demographic and education terms with the control dummies. In particular, control variables are defined as follows: demographic dummy (Dy=young), education dummy (De=primary), gender dummy ( $\mathrm{Df}=\mathrm{female})$, as well as country and time dummies. Finally, since the demographic and educational terms are defined at a different level of aggregation, we have to account for the 'common error' component by clustering errors by cohort and country.

The specification of the unemployment equation, as outlined in [2], is our base model, where $\alpha$ and $\beta$ are our parameters of interest. The demand side controls include: a cyclical term, proxied by the

\footnotetext{
16 In order to identify the model we need that both changes in educational attainment and cohort size (as measured using the "population" variable) do impact on the labour market. One case of concern could be related to the potential 'non participation' of the youngest cohorts, which would arise if the new generations choose either to study past age 24 (in which case they would necessarily be recorded as out of the labour force) or simply do not find the appropriate match for their skills and fall into the discouraged workers category (once again resulting out of the labour force). In either cases above unemployment would not be affected. To test whether this is the case we have first computed the share of those who, within the young cohort, quit school and end up unemployed; and second we have redefined our demographic shift using the labour force (i.e. the share of those in the age interval 15-24 over the labour force in the age interval 15-54) and regressed it against our Yshare variable (computed using the population). This gives us a coefficient of 0.94 (and s.e. 0.01), after controlling for country and year effect, suggesting that the two are highly correlated and that the demographic shift are not undone by labour market participation decision.

17 Our dependent variable is specified as log of unemployment rates (in levels) at the gender-cohort-education disaggregation. We discarded the "relative unemployment" specification since, as previously discussed, this would not allow us to disentangle changes affecting the numerator from changes affecting the denominator.
} 
deviation of GDP from its trend (deviation), and a skill-biased technical progress indicator, defined either as the $\log$ of the share of $\mathrm{R} \& \mathrm{D}$ expenditures over GDP $(\ln R \& D)$ or the $\log$ of the share of investment in ICT (Information and Communication Technology) over total investment (lnict). These variables are meant to capture the extent to which the composition of aggregate labour demand may be biased towards skilled workers ${ }^{19}$. Controlling for relative labour demand is important to identify the labour supply shocks originating from changes in demographic and education composition.

\subsection{Main results}

We start with OLS estimates for the base specification (in which $\ln R \& D$ is interacted with the education dummies) and report the results in Table 3. Cyclical and compositional terms show that (positive) deviations of GDP from its trend are negatively correlated with the unemployment rate, and that unemployment rates are on average lower for males, skilled workers and adults. These are common findings across all the various specifications.

[Tab.3]

The demographic term shows a positive elasticity (statistically significant) while the education term enters with a negative elasticity (when the alternative definition $\ln$ EshareY is used the demographic term is still positive but its significance is slightly reduced). These results seem to give support to the cohort-crowding hypothesis, which in times of baby busts implies that - everything else constant- there is an average beneficial effect (in terms of unemployment reduction) from the ageing of the population. The negative elasticity on the education term, contrary to the standard supply shock, seems to suggest that an increase in educational attainment is expected to reduce the unemployment rate. The skill-biased technical progress term is positively and significantly correlated with the unemployment rate of the unskilled while there is negative association with the unemployment rate of the skilled, but not statistically significant. These large effects on unemployment also seem to suggest the existence of some degree of (wage) rigidity in the labour market.

In order to assess whether the changes in demographics and education composition impact differently on, respectively, the young and adult cohorts (for the demographic) and the less educated

\footnotetext{
${ }^{18}$ For the Eshare variable we experiment the two different specifications discussed before: the share of more educated in the population as well as the share of the more educated within the younger cohort (i.e. EshareY).

${ }^{19}$ The ict_share variable is not available for Norway so we have set it to zero and let the country dummy pick up the effect.
} 
and more educated individuals (for the education composition), we have interacted each term with their respective dummies ${ }^{20}$. Results are reported in Table 4.

[Tab. 4]

The elasticity of unemployment to changes in Yshare is much higher for the young cohort than for the adult one - for whom it is also non significant (see col. 1 and 2). Note that an elasticity close to one means that a decrease of 1 percent in the share of youth in the population would decrease unemployment of the 15-24 cohort by an equal amount, while having no effect on the unemployment of adults ${ }^{21}$. In other words, these results support the view that young cohorts benefited relatively more from the baby bust when confronted to the adult cohort, which also implies a reduction in the relative young-adult unemployment rate $^{22}$. Conversely, when looking at the differential impact of the share of the more educated in the population (and within the young cohort) on unemployment, we find that an increase in the share of individuals with (upper) secondary education reduces joblessness with a higher elasticity for the more educated group (the coefficients on Eshare and EshareY are respectively, -0.569 and -0.336): hence, a one percentage increase in the share of the more educated will, ceteris paribus, decrease unemployment of the more educated by approximately half percentage point. For those with only primary education the effect is still negative but much smaller and not statistically significant. Simple OLS estimates, as previously discussed, may be biased due to the potential endogeneity of educational choices. In other words, while an increase in the share of educated people can have beneficial effects on employment and reduce unemployment, it cannot be excluded that depressed labour market conditions (i.e. unemployment), by lowering the opportunity cost of investing in education, are correlated to educational choices. Indeed when testing for the endogeneity of educational variables we could not reject the hypothesis that educational decisions are correlated with the residual of our unemployment equation so that IV estimation seems appropriate ${ }^{23}$. We need to find appropriate instruments that are correlated to the decision to invest in education and are uncorrelated with the residual in the unemployment equation. Under the assumption that current educational choices are made looking at the choices made by individuals of previous cohorts, then the share of individuals with upper secondary education or more in the adult cohort (which is a predetermined variable and

\footnotetext{
${ }^{20}$ In practice the interactions on the demographic and educational terms are (i.e. Dy=young; De=primary education), $D y * \ln Y$ share $+(1-D y) * \ln Y$ share $+D e * \ln$ Eshare $+(1-D e) * \ln$ Eshare .

${ }^{21}$ In the specification reported, we could not reject the hypothesis that the estimated coefficient is different from 1.

${ }^{22}$ Notice that this would have the effect of making the predicted relative unemployment rates closer to the observed ones, when compared to a naïve model that uses only gender, cohort, education, country and time dummies.

${ }^{23}$ To test endogeneity (i.e. correlation between the variable capturing the educational attainment of the population and the error in the unemployment equation) we perform a standard test augmenting the reduced form unemployment equation with the residual obtained from the auxiliary education equation. Results confirm that educational choices are
} 
thus by hypothesis uncorrelated with current unemployment) can be a potential instrument ${ }^{24}$. The results obtained with IV estimation are reported in Table 4 (col. 3 and 4). We still find a positive elasticity (also similar in magnitude) of demographic change to unemployment mainly for the young cohort (using either education variables and demand terms ${ }^{25}$ ). The elasticity of the share of the more educated is now negative and significant for both educational groups (still higher for the skilled) when using Eshare but it turns not statistically significant for the less educated group when using EshareY. Also a statistically significant positive effect on unemployment is associated to $R \& D$ expenditure for the group with lower education, probably capturing some form of labour skillbiased displacement effects ${ }^{26}$.

These results, after accounting for the endogeneity of educational choices and controlling for labour skill-biased demand shifts, show no evidence of a supply driven education-crowding effects (which would imply a positive correlation between the educational composition term and unemployment rates, at least for the skilled group). Indeed, if anything, a higher fraction of more educated in the population seems to produce favourable spill-over effect reducing also the unemployment rate of the less educated. Overall these results indicate that previous studies, by neglecting the effects of education, are unable to explain the full picture. Our results also confirm the standard crowding-out hypothesis to the benefit of the young unemployed. Note that this is at odds with models in which cohort size has a positive effect on the matching function, since here young cohorts, everything else constant, do better in the labour market because they are less numerous (and relatively more educated), not because they benefit from search externalities (see, Shimer, 2001). Also, we find that "education matters", in the sense that contrary to the standard supply-side story, here the share of those having more than primary education reduces overall unemployment, and this effect is even stronger for the more educated. One way to reconcile the different results is to consider the role of education - on both demand and supply - in the matching process occurring in the labour market, such that as the share of more educated people increases firms are more likely to post jobs and fill high-skill vacancies. This effect proves even stronger when wage rigidities constrain high-skill wages from increasing face to the increase in (high skilled) jobs. This is what we investigate in the next section.

potentially endogenous (i.e. the coefficient on the residual is statistically significant) so that OLS estimates are likely to be biased.

${ }^{24}$ The chosen instrument is highly correlated with both $\ln E$ share (coefficient 0.73 with a s.e. of 0.02 ) and $\ln E$ shareY (coefficient 0.61 with a s.e. of 0 . 07). In both cases we also controlled for country and year dummies. We also experimented, as instrument for the education term, the share of more educated individuals lagged one period. Results obtained are not significantly different from the ones reported in table 4, but lagged education is probably a less satisfactory instrument than the one chosen above hence results have not been reported.

${ }^{25}$ In Table 4, only results obtained when using $\ln R \& D$ are reported.

${ }^{26}$ Similar results are found when using lnict as a proxy for labour skill-biased demand. 


\subsection{Robustness}

In order to assess the overall robustness of the empirical results and gain additional insights from our estimates, we performed a number of sensitivity tests. We first looked at the predictive power of the model: our preferred specification (column 3 in Table 4), controlling for demand factors, cohort and education interactions, as well as country and time fixed effects, proved quite accurate in predicting differences in the evolution of unemployment patterns across countries. Next, we run our model separately by gender. The effect of changes in demographic and education composition on unemployment rates resulted much higher for females as compared to males: this probably reflects the higher sensitivity of female workers to labour market shocks and the marked increase in female tertiary education over the sample period. We also fitted our model experimenting a different specification for the dependent variable, namely: unemployment to population ratio, employment ratio and labour force. For example, to check the relevance of labour supply effects in our results, we used the (log of the) unemployment to population ratio (group specific ${ }^{27}$ ). Qualitatively, the results obtained are essentially unchanged, only some of the control variables show an attenuated effect. When we use the (log of the) employment rate results are symmetric with respect to those found when using the (log of the) unemployment rate. Finally we looked at labour force participation rate as our dependent variable. We found no significant correlation between labour force participation rate and the demographic shock (neither on the young nor for the adult group), while the education term is negative and statistically significant for the group with primary education and positive (but not significantly) for the more educated group.

Finally, we tested whether the elasticities between unemployment and the aggregate demographic and education variables were different in periods of baby boom as compared to baby bust. Under our preferred specification, we found that both elasticities are slightly larger in periods of baby boom (although the difference with baby bust periods is not always statistically significant). This result is in line with the literature and is consistent with the presence of some frictions in the labour market. Since the analysis has been performed pooling all countries together, we tested this restriction allowing demographic and education effects to differ between Southern and Northern countries $^{28}$. We find that demographic (positive) effects are stronger in Southern countries (with a similar impact on both adult and young cohorts), so as the effects of the changes in the education composition (which are not always statistically significant).

\footnotetext{
27 The cell is defined for country-time-gender-education and cohort specific aggregates for both terms in the unemployment-population ratio.

${ }^{28}$ In the first group we have Greece, Italy, Portugal and Spain, in the second group we have all the remaining countries.
} 
Also, since misspecification or measurement error could distort our estimates, we performed a number of tests and experimented with different specifications, different definitions for the explanatory variables and sensitivity to the inclusion of a different set of countries ${ }^{29}$. By including (or excluding) any of the countries considered at the time, main results did not change substantially.

Being concerned that our errors might be serially correlated we also regressed the (panel specific) errors on their one and two periods lag values, controlling for all the explanatory variables. We find some evidence for average first order autocorrelation coefficient (0.93). A more formal test for serial correlation,also indicates that the Null hypothesis of no first order serial correlation can be rejected ${ }^{31}$. Hence we re-estimated the model allowing for both panel specific heteroscedastic and serially correlated $(\mathrm{AR}(1))$ error structures, running a FGLS specification with robust error correction. While this does not address the endogeneity issue it improves upon the OLS specification since it allows for a more complex error structure. The results obtained are close to those obtained with OLS and robust error correction (the values for estimated coefficients tend to be lower when running FGLS). In general our preferred specifications proved highly robust to most of the sensitivity checks performed maintaining signs and (in almost all cases) statistical significance

\section{Economic and Institutional Factors}

In order to investigate whether institutional factors also play a role in the determination of unemployment rates (for different groups of individuals), after conditioning on demographic, educational, cyclical and technological terms, we augmented our preferred specification with a set of (time-varying) institutional indicators such as: employment protection (EPI), replacement ratios and duration of unemployment benefits (BR, BD), (net) union density (UDNET) and degree of coordination of the wage bargain (COI) (Blanchard and Wolfers, 2000; Katz and Autor, 1999; Belot and Van Ours, 2004; Layard and Nickell, 1999; Nickell et al., 2005).

Union density is introduced to capture union influence on wages and employment. Among other things, unions are expected to reduce wage flexibility and compress differentials such that ceteris paribus - the effect on unemployment is expected to be positive. Replacement ratios and duration of unemployment benefits, by improving the outside opportunities of workers and unions

\footnotetext{
${ }^{29}$ Detailed results of the sensitivity tests performed are reported in the data appendix and can be obtained upon request.

${ }^{30}$ We use a test as proposed by Wooldridge (2002), exploiting the properties of the error term in a first difference transformation of the data which should show a correlation coefficient of 0.5 in case of no serial correlation in the errors in levels The test simply checks whether there is statistical evidence suggesting an autocorrelation coefficient different from 0.5 .

${ }^{31}$ We use a test as proposed by Wooldridge (2002), exploiting the properties of the error term in a first difference transformation of the data which should show a correlation coefficient of 0.5 in case of no serial correlation in the errors in levels The test simply checks whether there is statistical evidence suggesting an autocorrelation coefficient different from 0.5 .
} 
in the bargaining process, are also expected to be positively associated to unemployment. Employment protection measures ${ }^{32}$ aim at protecting long term relationship vis-à-vis temporary work, as well as raising firing costs to reduce churning on the labour market. The impact on unemployment is likely to depend on the extent of transaction costs, compression of the wage structure and the relevance of specific human capital (Bertola and Rogerson, 1997). Finally, economies with more centralized wage setting institutions are expected to better internalize the wage-employment trade off and then should be associated to lower unemployment rates (Calmfors and Driffil, 1988). There is also evidence that demographics, macroeconomic shocks and institutions interact in a very diverse way across different groups of workers; in particular the burden of adjustment is often found to bear more on young workers (Bertola et al., 2002a). The latter can be explained in the light of the "two tier" mechanism of reforms, where high protection was granted to (adult) incumbent workers and more flexible rules applied to (young) labour market entrants.

[Table 5]

The main set of results are reported in Table 5. First, we introduce the variables capturing the institutional environment without any interaction (columns 1 and 2), then the institutional variables are interacted (columns 3 and 4) with the cohort dummies (in all cases we report both OLS and IV estimates) ${ }^{33}$. When the effects of the institutional environment are controlled for, we find that the estimated elasticities for the demographic terms are much larger (particularly for the young cohort) and statistically significant in most specification. The elasticities for the educational terms do not change dramatically, still the effects are stronger and statistically significant mainly for the group with secondary education or more. Focussing on the estimated coefficients of the institutional variables, we find that they matter: they are statistically significant both individually and jointly; and have (with only one exception) the expected sign. Both replacement ratios and (average) duration of unemployment benefits show strong displacement effects on unemployment. The negative sign on the variable capturing employment protection suggests that, when accounting for the skill composition of the labour force, the impact of some firing restraints on unemployment can be beneficial - i.e. reducing labour market churning and promoting long term employment relations.

\footnotetext{
32 The employment protection measure used is a weighed average of the overall strictness of protection against dismissal for "regular employment" (procedural inconvenience, advance notice and severance pay, and difficulty of dismissal), and the overall strictness of regulation for "temporary work" (which is a weighted average for the fixed-term contracts and the temporary work agency) published by OECD (1999).

${ }^{33}$ Under the assumption that institutions also impact differently on the more/less educated, we experimented interaction terms between labour market institutions and educational dummies. Results relative to the effects of institutions on unemployment confirm the main findings of table 5. Interaction terms indicate that $\mathrm{Bd}$ and Epi have a stronger effect for the less educated, while no (statistically) significant differences appear with respect to the other terms. Results are not reported here but are available from the authors upon request.
} 
The extent of centralization in the wage bargain, is also found to reduce unemployment. Union density, on the contrary, it is mostly not statistically significant and bears the wrong sign. When we interact the institutional factors with cohort dummies, we generally find that institutional changes occurred in recent decades (such as, decline in union density, lower generosity of unemployment benefits and less employment protection) have affected adult unemployment relatively more. Conversely, the process of decentralization in wage bargaining, while worsening the overall wage(un)employment trade-off, seem to have affected the employment opportunities of young more than those of adult workers. It is interesting to note that the negative effect of union density, when interacted with the cohort dummies, proves statistically significant for the adult group. In other words, controlling for demographic and education composition, it seems that the decline in union density occurred in most countries considered - ceteris paribus - did not contribute to improve the employment opportunities of the adult population in the labour market.

\section{Concluding remarks}

This paper has investigated the effects of demographic and educational change on the labour market position of workers, by gender, cohort and education, in a number of European countries. Results show that demographic and educational shocks are qualitatively different for young (adult) workers as well as for more (less) educated people. While adult workers and more educated individuals, in general, experience lower unemployment rates, changes in the population age structure ("baby bust") appear to be positively related to young workers' unemployment rates. Conversely changes in the skill structure ("education boom"), even when controlling for skillbiased technological change, reduce the unemployment of the more educated. In other words, we find that education matters: the share of those having more than compulsory education is found to be negatively related to the unemployment rate. This result is confirmed when the endogeneity of educational choices is accounted for using instrumental variables. Also labour market institution matter: unemployment benefits are found to have a positive impact on unemployment, while bargaining coordination and employment protection reduce it. One clear message from the above findings is that not distinguishing between demographic changes and shifts in the education composition (as well as controlling for institutions), as done in most previous studies, can be misleading as it provides a rather incomplete explanation of unemployment patterns.

The economic and policy implications of the above findings are of some interest, for the aging of the population, the increase in the demand for skilled labour, as well as the process of labour market reform are serious challenges for the performance of European labour markets in the light of the 
European Employment Strategy. In this context, few decades of "baby bust" demographic patterns seem to have significantly improved the position of young workers in the European labour market; while adult workers, particularly if low skilled, seem to have been more insulated and less sensitive to demographic and education shocks. This evidence, given the deterioration of the old-agedependency ratios in most European countries, requires growing efforts to increase employment rates as older cohort will approach retirement age. A more active role in the supply of education is also likely to be a key policy to improve employment opportunities of those (skilled) workers entering in the labour market. Increasing access to secondary education, reducing the number of those who drop out of school (early) and promoting enrolment into university, can prove - as the results show - very effective to increase employment ratios (in the population) and reduce unemployment (in the labour force). While, in some European countries, there is concern with respect to the effects of over-education, it should not be neglected that the challenges of a knowledge-based economy will require an increasing number of high skilled workers, as well as an adequate number of (high-skill) jobs posted by firms. Finally, labour market institutional reform also seem to play a crucial role in improving employment opportunities of workers. Labour market institutions and the process of reform seem to have affected young and prime-age workers differently, with reduced benefit generosity showing stronger (positive) effects on adult workers (vis-à-vis younger ones), de-regulation of employment protection measures also (negatively) affecting adult workers more, while bargaining decentralisation having a larger (negative) effect on younger cohorts. 


\section{References}

Acemoglu, D., Aghion, P. and Violante G. L. (2001) "Deunionization, technical change and inequality", Carnegie - Rochester conference series on public policy, 55, 229- 264

Acemoglu, D. (2003) “Cross-country inequality trends”, Economic Journal, 113, 121-149

Belot, M. and van Ours (2000), "Does the recent success of some OECD countries in lowering their unemployment rates lie in the clever design of their labour market reforms ?", CEPR wp.2492. Berger, M. C. (1985) "The effect of cohort size on earnings growth: a re-examination of the evidence", Journal of Political Economy, 93(3), 561-573

Bertola, G., Blau, F. and Kahn, L., (2002a), Comparative analysis of labor market outcomes: lessons for the US from international long run evidence, in Krueger, A. and Solow, R., eds., The roaring nineties: can full employment be sustained?, New York, Russell Sage.

Bertola, G., Blau, F. D. and Kahn, L. M. (2002b) "Labor market institutions and demographic employment patterns", NBER Working Paper 9043

Bertola, G. and Rogerson, R. (1997) “Institutions and Labor Reallocation”, European Economic Review, 41(6), 1147-71

Blanchard, O. and J. Wolfers (2000), "The role of shocks and institutions in the rise of European unemployment: the aggregate evidence", Economic Journal ,110: C1-C33.

Bloom, D. E. and Freeman, R. E. and Korenman, S. D. (1987) "The labour-market consequences of generational crowding", European Journal of Population, 3, 131-176

Brunello, G. and Lauer C. (2004) "Are wages in the Southern Europe more flexible? The effects of cohort size on European earnings", IZA Discussion paper 1299

Brunello, G., Comi, S. and Lucifora C. (2000) "The College wage gap in 10 European countries: evidence from two cohorts, IZA Discussion paper 228

Calmfors, L., and J. Driffill. (1988). Centralisation of wage bargaining and macroeconomic performance, Economic Policy, 6, 13-61.

Card D. and Lemieux T. (2001) "Can falling supply explain the rising return to college for younger men? A cohort-based analysis, Quarterly Journal of Economics, 116(2), 405-476

EU-IRS (2002), "The economic cost of the Skill Gap in the EU", Report on behalf of EU-DGV, IRS, Milan.

Flaim, P. O. (1979) “ The effect of demographic changes on the Nation's unemployment rate”, Monthly Labor Review, 102, 13-23

Flaim, P. O. (1990) "Population changes, the baby boom, and the unemployment rate", Monthly Labor Review, 113, 3-10 
Flinn, C. J. (1993) “The implications of cohort size human capital investment”, in P. Johnson and Zimmerman, K., eds. Labour Markets in an Ageing Europe, Cambridge University Press

Hartog, J., Oosterbeek and Teulings C. (1993) "Age, Wages and Education in the Netherlands", in P. Johnson and Zimmerman, K., eds. Labour Markets in an Ageing Europe, Cambridge University Press

Jimeno, J. F. and Rodriguez-Palenzuela, D. (2002) "Youth unemployment in the OECD: demographic shifts, labour market institutions, and macroeconomic shocks", ECB Working paper 155

Johnson, P. and Zimmermann, K. F. (1993) Labour markets in an ageing Europe, Cambridge University Press

Katz L. and Autor, D. (1999) "Changes in the wage structure and earnings inequality", in Ashenfelter, O. Card, D. (eds.), Handbook of Labor Economics, Elsevier Science, North-Holland, Volume 3C, 2089-2125

Korenman, S. and Neumark, D., (2000), Cohort crowding and youth labor markets: a cross sectional analysis, in Blanchflower, D., and Freeman, R., eds., Youth employment and joblessness in advanced countries, NBER, Chicago University Press.

Layard, R. and S.Nickell (1999). "Labor Market Institutions and Economic Performance" in Ashenfelter, O. Card, D. (eds.), Handbook of Labor economics. Elsevier Science, NorthHolland, Volume 3C, 3029-84

Nardone, T. (1987) "Decline in youth population does not lead to lower jobless rates", Monthly Labor Review, 110, 37-41

Nickell, S. (1993) "Cohort size effects on the wages of young men in Britain, 1961-1989", British Journal of Industrial Relations, 31(3), 459-469

Nickell, S. and Bell, B. (1996) "Changes in the distribution of wages and unemployment in OECD countries", American Economic Review, papers and proceedings, 86, 302-308

Nickell S., Nunziata L. and Ochel W. (2005) Unemployment in the OECD since the 1960s. what do we know?, Economic Journal, 115, 1-27

Nordstrom Skans, O. (2002) “Age effects in Swedish local labour markets”, Institute for Labour Market Policy Evaluation, Working paper n. 2002:11

OECD (1986) Employment Outlook, Paris

OECD (1999), Employment Outlook, Paris

Shimer, R. (2001) "The impact of young workers on the aggregate labor market", Quarterly Journal of Economics, 116(3), 969-1007 
Stapleton, D.C, and Young, D. J. (1988) "Educational attainment and cohort size", Journal of Labor Economics, 6(3), 330-361

Welch, F. (1979) “Effects of cohort size on earnings: the baby boom babies' financial bust”, Journal of Political Economy, 87(5), s65-s97

Wooldridge, J. M. (2002) Econometric analysis of cross section and panel data, MIT Press, Cambridge Mass.

Wright, R. (1991) “Cohort size and earnings in Great Britain”, Journal of Population Economics, 4, 295-305

Zimmermann, C. (1991) "Ageing and the labor market: Age structure, cohort size and unemployment", Journal of Population Economics, 4(3), 177-200 


\section{Data Appendix}

Table A1 - Variables description

\begin{tabular}{|c|c|}
\hline Variables & Description \\
\hline \multicolumn{2}{|r|}{ Demographic and Education terms (*) } \\
\hline un & Unemployment rate (by gender, cohort, education, country, year) \\
\hline Yshare & $\begin{array}{l}\text { Share of the population in the } 15-24 \text { age interval within the population in } \\
\text { the age interval } 15-54, \text { (by country, time) }\end{array}$ \\
\hline Eshare & $\begin{array}{l}\text { Share of those with more than primary education within the population in } \\
\text { the age interval } 15-54, \text { (by country, time) }\end{array}$ \\
\hline EshareY & $\begin{array}{l}\text { Share of those with more than primary education within the } 15-24 \text { cohort, } \\
\text { (by country, time) }\end{array}$ \\
\hline \multicolumn{2}{|r|}{ Institutions (\#) } \\
\hline Udnet & $\begin{array}{l}\text { Union density: ratio of Total Reported Union Members (gross minus retired } \\
\text { and unemployed members) on Wage and Salaried Employees }\end{array}$ \\
\hline Epi & $\begin{array}{l}\text { employment protection index: range is }\{0,2\} \text { increasing with strictness of } \\
\text { employment protection }\end{array}$ \\
\hline$B d$ & $\begin{array}{l}\text { Benefit Duration index: weighted average of the unemployment benefit } \\
\text { replacement rate perceived from the first year of unemployment to the } \\
\text { fourth year of unemployment (with decreasing weights) }\end{array}$ \\
\hline$B r$ & $\begin{array}{l}\text { Benefit Replacement Rate: first year of unemployment benefits, averaged } \\
\text { over family composition by recipients }\end{array}$ \\
\hline Coi & $\begin{array}{l}\text { Bargaining Coordination: index increasing in the degree of coordination in } \\
\text { the bargaining process on the employers' as well as on the unions' side } \\
\text { (range }[1,3])\end{array}$ \\
\hline \multicolumn{2}{|r|}{ Demand terms $\left({ }^{\circ}\right)$} \\
\hline$R \& D$ & Share of expenditures in R\&D over GDP (by country, time) \\
\hline Ict & Share of investment in Ict over total investment (by country, time) \\
\hline Deviation & Demand shifter (by country, time) \\
\hline \multicolumn{2}{|r|}{ Control dummies } \\
\hline Dy & demographic dummy Dy=young \\
\hline$D f$ & gender dummy (Df=female) \\
\hline$D e$ & education dummy (De=primary), \\
\hline$D C$ & Country dummies \\
\hline$D t$ & Year dummies \\
\hline
\end{tabular}

Source: (*) National Labour Force Surveys (various years); (\#) Data from Nickell and Nunziata (2005);

$\left({ }^{\circ}\right)$ OECD Database and ENERDATA 
Table 1 - Country coverage, statistical sources and time period

\begin{tabular}{|l|l|l|}
\hline Country & Source & years available \\
\hline Finland & Labour Force Survey & $1982,1989,1991,1992$ and 1994-2002 \\
\hline France & Labour Force Survey & $1983-2001$ \\
\hline Germany & Labour Force Survey & $1991,1992,1994-2002$ \\
\hline Greece & Labour Force Survey & $1987-2002$ \\
\hline Italy & Labour Force Survey & $1978-2001$ \\
\hline Norway & Labour Force Survey & $1975-2002$ \\
\hline Portugal & Labour Force Survey & $1989,1991,1994-1996,1998-2002$ \\
\hline Spain & Labour Force Survey & $1977-2002$ \\
\hline Sweden & Labour Force Survey & $1986-2002$ \\
\hline U.K. & Labour Force Survey and General & $1980-2000$ (biannual from 1996) \\
\hline
\end{tabular}



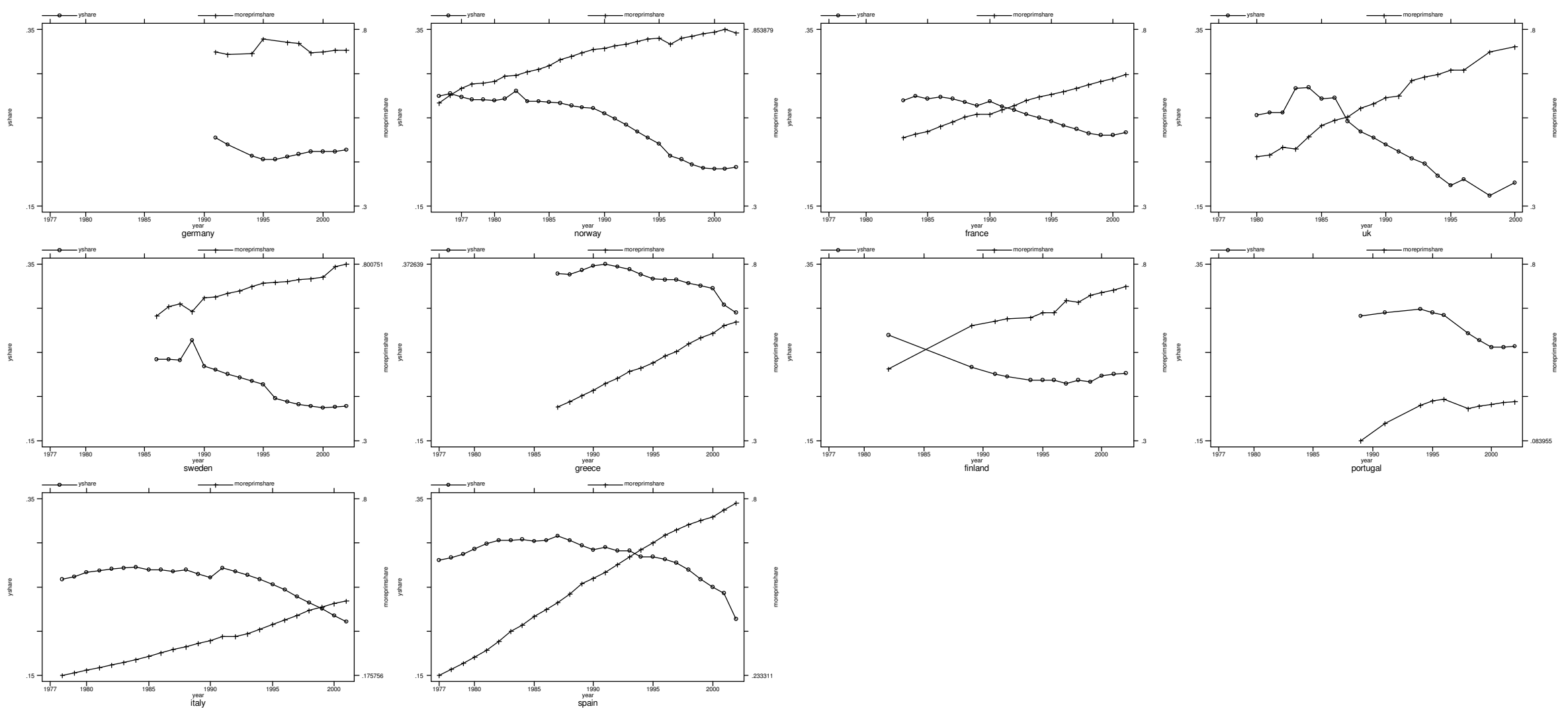

Fig.1: Youth and Education shares 
Table 2 - Average Unemployment Rates by Cohort and Education (1991 - 2002)

\begin{tabular}{|l|c|c|c|c|c|c|}
\hline \multirow{3}{*}{ Country } & \multicolumn{3}{|c|}{ Cohort } & \multicolumn{3}{c|}{ Education } \\
\cline { 2 - 7 } & $\begin{array}{c}\text { Young } \\
(\mathrm{Y})\end{array}$ & $\begin{array}{c}\text { Adult } \\
(\mathrm{A})\end{array}$ & Y/A & $\begin{array}{c}\text { Primary } \\
(\mathrm{P})\end{array}$ & $\begin{array}{c}\text { Secondary } \\
\text { or more } \\
(\mathrm{S})\end{array}$ & $\mathrm{P} / \mathrm{S}$ \\
\hline Finland & 0.25 & 0.10 & 2.39 & 0.20 & 0.17 & 1.18 \\
\hline France & 0.22 & 0.09 & 2.42 & 0.14 & 0.15 & 0.93 \\
\hline Germany & 0.08 & 0.08 & 1.06 & 0.11 & 0.08 & 1.38 \\
\hline Greece & 0.29 & 0.10 & 3.05 & 0.16 & 0.22 & 0.73 \\
\hline Italy & 0.38 & 0.10 & 3.74 & 0.20 & 0.26 & 0.77 \\
\hline Norway & 0.11 & 0.04 & 3.19 & 0.08 & 0.07 & 1.14 \\
\hline Portugal $\S$ & 0.12 & 0.05 & 2.45 & 0.08 & 0.09 & 0.89 \\
\hline Spain & 0.34 & 0.16 & 2.15 & 0.25 & 0.25 & 1.00 \\
\hline Sweden & 0.12 & 0.05 & 2.33 & 0.08 & 0.08 & 1.00 \\
\hline U.K. § & 0.16 & 0.07 & 2.26 & 0.16 & 0.09 & 1.78 \\
\hline
\end{tabular}

Source: National Labour Force Survey (various years)

Notes: $\S$ ratios are computed on fewer data points (UK up to 2000; Portugal 1992,1993 and 1997 missing) 
Figure 2 - Supply and demand for skill among the young cohort

(a) Young-Low educated

(b) Young-High educated
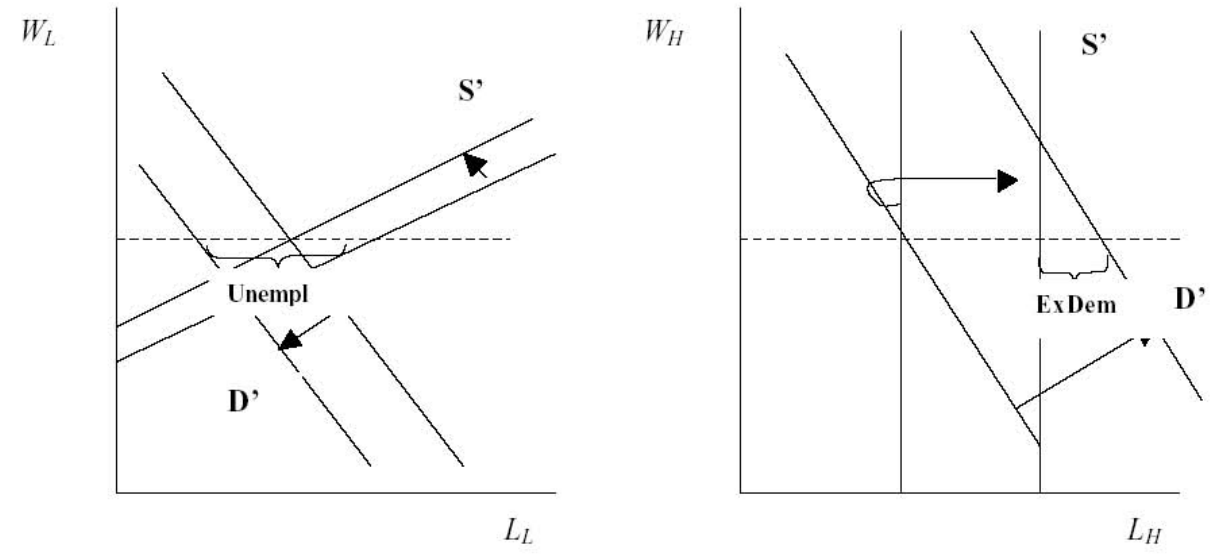
Table 3 - Estimates of Unemployment equations with Demographic and Education

\begin{tabular}{|l|c|c|}
\hline \multicolumn{1}{|c|}{ Model } & (1) & (2) \\
\hline \multicolumn{1}{|c|}{ variables } & Ln (une_rate) & In (une_rate) \\
\hline Ln(Yshare) & OLS & OLS \\
\hline Ln (Eshare) & 0.5454 & 0.3640 \\
& $(0.2166)$ & $(0.2035)$ \\
\hline Ln (EshareY) & -0.3518 & - \\
\hline Ln (R\&D)*De & $(0.1091)$ & -0.1798 \\
& - & $(0.0748)$ \\
\hline Ln (R\&D)*(1-De) & 0.1587 & 0.1728 \\
& $(0.0376)$ & $(0.0372)$ \\
\hline Deviation & -0.0550 & -0.0409 \\
& $(0.0372)$ & $(0.0369)$ \\
\hline Dy & -0.0002 & $(0.00002)$ \\
\hline Df & $(0.00002)$ & 1.0193 \\
& 1.0193 & $(0.0204)$ \\
\hline De & $(0.0204)$ & 0.2390 \\
& 0.2390 & $(0.0204)$ \\
\hline constant & $(0.0204)$ & 0.2821 \\
& 0.2821 & $(0.0221)$ \\
\hline Country dummies** & $(0.0221)$ & -3.6653 \\
\hline Year dummies & -3.4739 & $(0.3392)$ \\
\hline R-square & $(0.3352)$ & Yes \\
\hline N-obs & Yes & Yes \\
\hline
\end{tabular}

Notes: robust standard errors are in parentheses.

Dummy variables are indicated with a "D" before the variable name 
Table 4 - Estimates of Unemployment equations with Demographic and Education

\begin{tabular}{|c|c|c|c|c|}
\hline Model & $(1)$ & $(2)$ & (3) & $(4)$ \\
\hline \multirow[t]{2}{*}{ variables } & In (une_rate) & In (une_rate) & In (une_rate) & Ln (une_rate) \\
\hline & OLS & OLS & IV & IV \\
\hline Ln (Yshare)*Dy & $\begin{array}{c}0.9758 \\
(0.2203)\end{array}$ & $\begin{array}{c}0.7930 \\
(0.2086)\end{array}$ & $\begin{array}{c}1.0893 \\
(0.2727)\end{array}$ & $\begin{array}{c}0.9322 \\
(0.2675)\end{array}$ \\
\hline Ln (Yshare)* (1-Dy) & $\begin{array}{c}0.1211 \\
(0.2272)\end{array}$ & $\begin{array}{l}-0.0616 \\
(0.2142)\end{array}$ & $\begin{array}{c}0.2346 \\
(0.2830)\end{array}$ & $\begin{array}{c}0.0775 \\
(0.2766)\end{array}$ \\
\hline Ln (Eshare) ${ }^{2} \mathrm{De}$ & $\begin{array}{l}-0.1336 \\
(0.1185)\end{array}$ & - & $\begin{array}{c}-0.2898 \\
(0.1439) \\
\end{array}$ & - \\
\hline $\operatorname{Ln}($ Eshare $) *(1-\mathrm{De})$ & $\begin{array}{c}-0.5698 \\
(0.1191)\end{array}$ & - & $\begin{array}{l}-0.7412 \\
(0.1437)\end{array}$ & - \\
\hline Ln (EshareY)*De & - & $\begin{array}{l}-0.0237 \\
(0.0923)\end{array}$ & - & $\begin{array}{c}-0.205 \\
(0.1996)\end{array}$ \\
\hline $\operatorname{Ln}($ EshareY $) *(1-\mathrm{De})$ & - & $\begin{array}{l}-0.3360 \\
(0.0937)\end{array}$ & - & $\begin{array}{l}-0.9475 \\
(0.2053)\end{array}$ \\
\hline $\operatorname{Ln}(R \& D) \star D e$ & $\begin{array}{c}0.1131 \\
(0.0374)\end{array}$ & $\begin{array}{c}0.1528 \\
(0.0367) \\
\end{array}$ & $\begin{array}{c}0.1011 \\
(0.0414)\end{array}$ & $\begin{array}{c}0.1065 \\
(0.0439) \\
\end{array}$ \\
\hline $\operatorname{Ln}(R \& D) *(1-D e)$ & $\begin{array}{l}-0.0076 \\
(0.0365)\end{array}$ & $\begin{array}{c}-0.0199 \\
(0.0363)\end{array}$ & $\begin{array}{c}-0.0165 \\
(0.0399)\end{array}$ & $\begin{array}{l}-0.0097 \\
(0.0418)\end{array}$ \\
\hline Deviation & $\begin{array}{c}-0.0002 \\
(0.00002)\end{array}$ & $\begin{array}{c}-0.0002 \\
(0.00002)\end{array}$ & $\begin{array}{c}-0.0002 \\
(0.00002)\end{array}$ & $\begin{array}{c}-0.0002 \\
(0.00002)\end{array}$ \\
\hline Dy & $\begin{array}{c}2.1947 \\
(0.1625)\end{array}$ & $\begin{array}{c}2.1947 \\
(0.1621)\end{array}$ & $\begin{array}{c}2.1947 \\
(0.2122)\end{array}$ & $\begin{array}{c}2.1947 \\
(0.2178)\end{array}$ \\
\hline $\mathrm{Df}$ & $\begin{array}{c}0.2390 \\
(0.0195)\end{array}$ & $\begin{array}{c}0.2390 \\
(0.0198)\end{array}$ & $\begin{array}{c}0.2390 \\
(0.0255)\end{array}$ & $\begin{array}{c}0.2390 \\
(0.0267)\end{array}$ \\
\hline $\mathrm{De}$ & $\begin{array}{c}0.5352 \\
(0.0391) \\
\end{array}$ & $\begin{array}{c}0.4802 \\
(0.0406)\end{array}$ & $\begin{array}{c}0.5440 \\
(0.0516)\end{array}$ & $\begin{array}{c}0.7530 \\
(0.0922)\end{array}$ \\
\hline Constant & $\begin{array}{l}-4.1854 \\
(0.3418)\end{array}$ & $\begin{array}{l}-4.3506 \\
(0.3505)\end{array}$ & $\begin{array}{c}-4.1578 \\
(0.4079)\end{array}$ & $\begin{array}{l}-4.7557 \\
(0.4473)\end{array}$ \\
\hline Country dummies** & Yes & Yes & Yes & Yes \\
\hline Year dummies & Yes & Yes & Yes & Yes \\
\hline R-square & 0.826 & 0.821 & 0.826 & 0.808 \\
\hline $\mathrm{N}-\mathrm{obs}$ & 1456 & 1456 & 1456 & 1456 \\
\hline
\end{tabular}

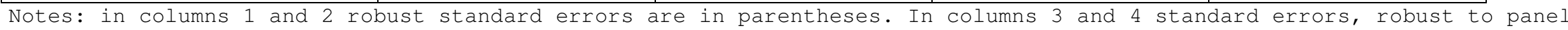
heteroscedasticity and serial correlation, are in parentheses.

* Dummy variables are indicated with a " $D$ " before the variable name

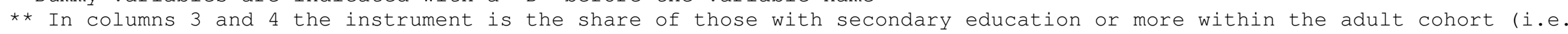
in the age interval 25-54). 
Table 5- Estimates of Unemployment equations with Demographic, Education and Institutions

\begin{tabular}{|c|c|c|c|c|c|}
\hline Model & $(1)$ & (2) & (3) & $(4)$ & \\
\hline Variables & Ln (une_rate) & Ln (une_rate) & Ln (une_rate) & Ln (une_rate) & \\
\hline & OLS & IV & OLS & IV & \\
\hline Ln (Yshare)*Dy & $\begin{array}{c}1.643 \\
(0.3011)\end{array}$ & $\begin{array}{c}1.7980 \\
(0.3569)\end{array}$ & $\begin{array}{c}1.4702 \\
(0.2787)\end{array}$ & $\begin{array}{c}1.6253 \\
(0.3282)\end{array}$ & \\
\hline Ln (Yshare)* (1-Dy) & $\begin{array}{c}0.4617 \\
(0.3063)\end{array}$ & $\begin{array}{c}0.6168 \\
(0.3647)\end{array}$ & $\begin{array}{c}0.6344 \\
(0.2955)\end{array}$ & $\begin{array}{c}0.7895 \\
(0.3510)\end{array}$ & \\
\hline Ln (Eshare) $* \mathrm{De}$ & $\begin{array}{c}-0.1409 \\
(0.1299)\end{array}$ & $\begin{array}{c}-0.3264 \\
(0.1433)\end{array}$ & $\begin{array}{c}-0.1409 \\
(0.1277)\end{array}$ & $\begin{array}{c}-0.3264 \\
(0.1413)\end{array}$ & \\
\hline Ln (Eshare)* (1-De) & $\begin{array}{l}-0.6760 \\
(0.1325)\end{array}$ & $\begin{array}{l}-0.9158 \\
(0.1473)\end{array}$ & $\begin{array}{l}-0.6760 \\
(0.1305)\end{array}$ & $\begin{array}{l}-0.9158 \\
(0.1455)\end{array}$ & \\
\hline Udnet & $\begin{array}{c}-0.5475 \\
(0.3748)\end{array}$ & $\begin{array}{c}-0.5957 \\
(0.4510)\end{array}$ & & & \\
\hline Udnet*Dy & & & $\begin{array}{l}-0.2999 \\
(0.3471)\end{array}$ & $\begin{array}{l}-0.3480 \\
(0.4132)\end{array}$ & \\
\hline Udnet* (1-Dy) & & & $\begin{array}{l}-0.7951 \\
(0.3474)\end{array}$ & $\begin{array}{c}-0.8433 \\
(0.4143)\end{array}$ & \\
\hline$\overline{E p i}$ & $\begin{array}{c}-0.9654 \\
(0.1095)\end{array}$ & $\begin{array}{c}-1.0173 \\
(0.1334)\end{array}$ & & & \\
\hline Epi*Dy & & & $\begin{array}{l}-0.8023 \\
(0.1119)\end{array}$ & $\begin{array}{l}-0.8541 \\
(0.1376)\end{array}$ & \\
\hline Epi* (1-Dy) & & & $\begin{array}{l}-1.1286 \\
(0.1204)\end{array}$ & $\begin{array}{c}-1.1804 \\
(0.1482)\end{array}$ & \\
\hline$\overline{B d}$ & $\begin{array}{c}1.1068 \\
(0.2268)\end{array}$ & $\begin{array}{c}1.0829 \\
(0.2691)\end{array}$ & & & \\
\hline $\mathrm{Bd}{ }^{\star} \mathrm{Dy}$ & & & $\begin{array}{c}0.9328 \\
(0.2132)\end{array}$ & $\begin{array}{c}0.9090 \\
(0.2526)\end{array}$ & \\
\hline $\mathrm{Bd}^{\star}(1-\mathrm{Dy})$ & & & $\begin{array}{c}1.2807 \\
(0.2225)\end{array}$ & $\begin{array}{c}1.2568 \\
(0.2633)\end{array}$ & \\
\hline$\overline{B r}$ & $\begin{array}{c}1.2564 \\
(0.2096)\end{array}$ & $\begin{array}{c}1.1438 \\
(0.2473)\end{array}$ & & & \\
\hline$B r * D y$ & & & $\begin{array}{c}0.9770 \\
(0.1983)\end{array}$ & $\begin{array}{c}0.8644 \\
(0.2312)\end{array}$ & \\
\hline $\mathrm{Br}^{*}(1-\mathrm{Dy})$ & & & $\begin{array}{c}1.5357 \\
(0.2010)\end{array}$ & $\begin{array}{c}1.4231 \\
(0.2363)\end{array}$ & \\
\hline$\overline{C o i}$ & $\begin{array}{c}-0.8570 \\
(0.0898)\end{array}$ & $\begin{array}{c}-0.8311 \\
(0.1080)\end{array}$ & & & \\
\hline Coi*Dy & & & $\begin{array}{l}-0.9853 \\
(0.0897)\end{array}$ & $\begin{array}{c}-0.9594 \\
(0.1061)\end{array}$ & \\
\hline Coi* (1-Dy) & & & $\begin{array}{l}-0.7287 \\
(0.0925)\end{array}$ & $\begin{array}{l}-0.7028 \\
(0.1116)\end{array}$ & \\
\hline $\operatorname{Ln}(R \& D) * D e$ & $\begin{array}{l}-0.0096 \\
(0.0408)\end{array}$ & $\begin{array}{l}-0.0292 \\
(0.0450)\end{array}$ & $\begin{array}{l}-0.0096 \\
(0.0396)\end{array}$ & $\begin{array}{l}-0.0292 \\
(0.0438)\end{array}$ & \\
\hline $\operatorname{Ln}(R \& D) *(1-D e)$ & $\begin{array}{l}-0.0152 \\
(0.0389)\end{array}$ & $\begin{array}{l}-0.0160 \\
(0.0433)\end{array}$ & $\begin{array}{l}-0.0152 \\
(0.0378)\end{array}$ & $\begin{array}{l}-0.0160 \\
(0.0421)\end{array}$ & \\
\hline Deviation & $\begin{array}{c}-0.0003 \\
(0.00002)\end{array}$ & $\begin{array}{c}-0.0003 \\
(0.00002)\end{array}$ & $\begin{array}{c}-0.0003 \\
(0.00002)\end{array}$ & $\begin{array}{c}-0.0003 \\
(0.00002)\end{array}$ & \\
\hline Dy & $\begin{array}{c}2.6727 \\
(0.1967)\end{array}$ & $\begin{array}{c}2.6727 \\
(0.2479)\end{array}$ & $\begin{array}{c}2.4461 \\
(0.3419)\end{array}$ & $\begin{array}{c}2.4461 \\
(0.4429)\end{array}$ & \\
\hline $\mathrm{Df}$ & $\begin{array}{c}0.1883 \\
(0.0192)\end{array}$ & $\begin{array}{c}0.1883 \\
(0.0250)\end{array}$ & $\begin{array}{c}0.1883 \\
(0.0179)\end{array}$ & $\begin{array}{c}0.1883 \\
(0.0231)\end{array}$ & \\
\hline $\mathrm{De}$ & $\begin{array}{c}0.6068 \\
(0.0398)\end{array}$ & $\begin{array}{c}0.6393 \\
(0.0514)\end{array}$ & $\begin{array}{c}0.6068 \\
(0.0363)\end{array}$ & $\begin{array}{c}0.6393 \\
(0.0470)\end{array}$ & \\
\hline constant & $\begin{array}{c}0.0201 \\
(0.7766)\end{array}$ & $\begin{array}{c}0.0828 \\
(0.9153)\end{array}$ & $\begin{array}{c}0.1334 \\
(0.7681)\end{array}$ & $\begin{array}{c}0.1961 \\
(0.9021)\end{array}$ & \\
\hline Country dummies** & Yes & Yes & Yes & Yes & \\
\hline Year dummies & Yes & Yes & Yes & Yes & \\
\hline R-square & 0.8492 & 0.8486 & 0.8696 & 0.8690 & \\
\hline $\mathrm{N}-\mathrm{obs}$ & 1328 & 1328 & 1328 & 1328 & \\
\hline \multicolumn{6}{|c|}{$\begin{array}{l}\text { Notes: in columns } 1 \text { and } 3 \text { robust standard errors are in parentheses. In columns } 2 \text { and } 4 \text { standard } \\
\text { errors, robust to panel heteroscedasticity and serial correlation, are in parentheses. } \\
\text { * Dummy variables are indicated with a "D" before the variable name } \\
\text { ** In columns } 2 \text { and } 4 \text { the instrument is the share of those with secondary education or more within } \\
\text { the adult cohort (i.e. in the age interval 25-54). } \\
\text { ** Greece is not included. }\end{array}$} \\
\hline
\end{tabular}

